\title{
Brand Relationships: A Personality-Based Approach
}

\author{
Helena M. Nobre' ${ }^{1}$ Kip Becker ${ }^{2}$, Carlos Brito ${ }^{3}$ \\ ${ }^{1}$ Instituto Superior de Administração e Gestão (ISAG), Rua do campo Alegre, Portugal; ${ }^{2}$ Administrative Sciences Department, Bos- \\ ton University, Boston, USA; ${ }^{3}$ Universidade do Porto-Faculdade de Economia, R. Dr. Roberto Frias, Portugal. \\ Email: hnobre2@gmail.com, kbecker@bu.edu,cbrito@fep.up.pt
}

Received February $21^{\text {st }}, 2010$; revised April $2^{\text {nd }}, 2010$; accepted May $8^{\text {th }}, 2010$.

\begin{abstract}
The authors investigated the relationship between brand personality and brand relationships. The conceptual model was based on the hypothesis that brand personality may nurture specific consumer-brand relationships and that these relationships may influence the quality of the ties that consumers develop with brands. An instrument from intimate interpersonal relationships was used to measure consumer-brand relationships. An SEM analysis conducted on a sample of 733 consumer-brand relationships, involving nine highly known brands of different product categories, gave support to the theory. The research offers two significant contributions by: 1) Emphasizing the role of consumer-brand relationship in understanding multi-brand, symbolic consumption and 2) Offering a holistic perspective in the understanding of brand personality.
\end{abstract}

Keywords: Brand Personality, Brand Relationships, Interpersonal Relationship Theory

\section{Introduction}

Some authors consider brand as a partner in a dyadic relationship with the consumer [1-6]. The relational approach may provide a better and broader understanding of the phenomena that arises between the customer and the brand. Investigating branding as a variable of consumer loyalty and customer retention may reduce influences resulting from symbolic consumption [7] since loyalty may be considered as a specific kind of a relationship [8]. Adopting a relational view of consumption is more consistent with the need to develop a more holistic approach of brand knowledge [9].

In 1998, in an innovator approach, Susan Fournier used the inter-personal relationship metaphor to study consumer-brand relationships. Susan Fournier postulated that brand is a partner in a dyadic relationship with the consumer highlighting the holistic character of the phenomena. She concluded that consumer-brand relationships are a source of self-efficacy, self-esteem and self-identity.

Building on Fournier's study, J. Aaker et al. [2] developed a conceptual model to explain consumerbrand relationships which was based on the fact that acts of transgression and brand personality have a prominent role in the relationship strength formation. They reported two classes of relationships related to the brand personalities of Sincerity and Excitement $[10,11]$ which rely on the same constructs of the two Ideals of Relationships: Intimacy-Loyalty and Passion [12]. A review of the consumer-brand relationship research indicated there was a need for further investigation in order to understand the type of bonds different consumers establish with distinct brand personalities, as well as the relevant relationship patterns that can affect consumer-brand interactions.

Recognizing this research gap, the researchers were motivated to develop a conceptual model whose premise was that a brand's personality has an important role in the establishment of ties with the consumer. The hypothesis, that brand personality may nurture specific types of consumer-brand relationships and these consumerbrand relationships may influence the quality of the ties that consumers develop with brands, was constructed to test the model.

\section{A Framework for Brand Personality}

Utilizing a multivariate analysis design, J. Aaker [10] developed the Brand Personality Scale which is a five-factorial model operationalized in terms of human characteristics and was inspired by the Big Five model of human personality [13-15]. Despite its importance in the representation and explanation of brand personality [9], the scale is not generalizable to different cultures. As a result, J. Aaker et al. [11] developed transcultural studies 
in order to adjust the scale to other populations: the Japanese and Spanish populations.

The Spanish model included two universal factors-Sincerity and Excitement-as well as three culture specific factors. These are Passion (a specific element of Latin culture), Peacefulness (a shared element with the Japanese scale), and Sophistication (a mist of markers of North American Sophistication and North American Competence).

\section{Interpersonal Intimate Relationships}

In a new approach to the interpersonal relationships field, Fletcher et al. [12] developed the Relationship Ideals, a factorial model for explaining intimate (romantic) relationships, which is composed of two basic factors: Intimacy-Loyalty and Passion. Relationships of IntimacyLoyalty are caring, respectful, honest, trusting and supportive; and relationships of Passion are related to feelings of excitement, fun and independence. The authors note that results may not necessarily be generalized to other relationship domains and social contexts but that issue could represent an interesting direction of research.

According to Aggarwall [3], customers will relate to brands in ways that resemble their social ties. Aggarwall further states that the norms of interpersonal relationships are a basis for the assessment that customers make of their relationships with brands. This study advances the assumption that the Relationship Ideal Scale [12] is applicable to the consumer-brand relationship context.

\section{The Conceptual Model}

Building on the literature cited previously, the authors developed a conceptual model bringing together elements of several prior researchers (see Figure 1).
In an interpersonal-relationship theory perspective, Altman and Taylor [16] considered that the development of a relationship implies the gradual overlapping and exploration of the mutual selves of the partners involved in that relationship. They admit an unequivocal relevance of some features of personality on interpersonal processes. It seems plausible, therefore, that there would be a relationship between brand personality and the type of relationship the customer establishes with the brand. On one hand, brand personality is partially determined by the experiences the consumers develop with that brand. On the other, it acts as a base of information which provides guidance to consumers on the establishment of their relationships with brands [3] and influence the quality, or strength, of those ties [2]. Considering these facts, the authors posited the follow hypotheses:

H1: Brand Personality will be a predictor of Consumer-Brand Relationships.

H2: Brand Personality will be a predictor of Relationship Strength.

Brand personality is one potential source of relationship expectations [17], in particular those relationship expectations relating to partner quality based on the sum of inferences consumers make through the observation of a brand's behaviours [4]. The partner quality inferences have a foundation in judgements of equity and justice, in socioemotional benefits, and have the purpose of defining the belief the customer has in his relationship with a brand [2]. Therefore, partner quality can be considered to be a mediating variable between brand personality and consumer-brand relationship:

H3: The influence of Brand Personality on ConsumerBrand Relationships will be partially mediated by the consumer perceptions of Partner Quality.

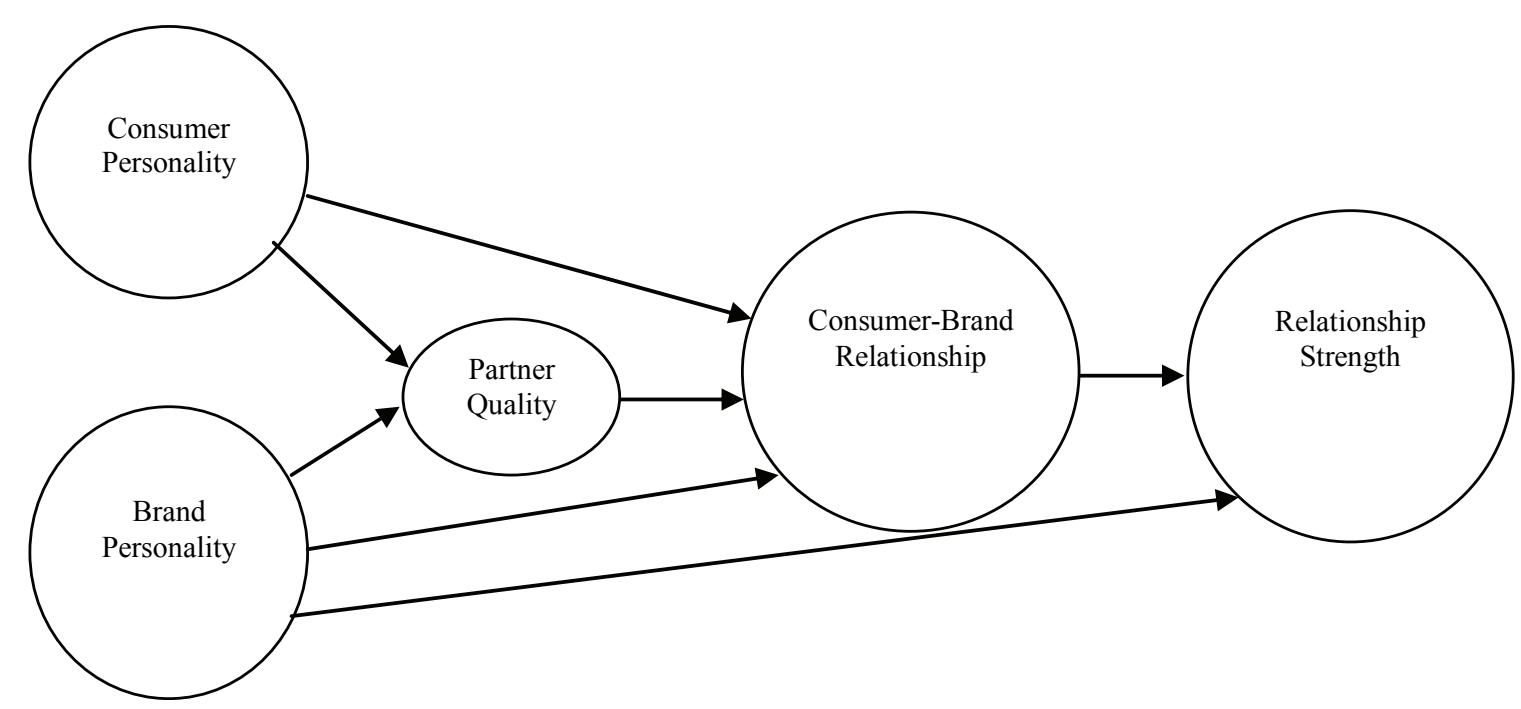

Figure 1. Conceptual model of the influence of brand personality on consumer-brand relationship 
In the literature, longevity of a relationship is associated with the quality and stability [6] or the strength of that relationship [18]. Moreover, the characterization of the two Relationship Ideals proposed by Fletcher et al. (1999) [12] indicated that relationships of IntimacyLoyalty, rather relationships of Passion, are associated with lasting relationships. These are based on patterns of commitment, trust and intimacy. Considering this, it was hypothesized:

H4: The type of Consumer-Brand Relationship will be a predictor of Relationship strength.

The personality of the partners in a relationship influences the content and the development of that relationship [19]. Thus, it is expected that:

H5: Consumer Personality will be a predictor of Consumer-Brand Relationships.

According to Auhagen and Hinde [20], partner personality influences the behaviours in a relationship and biases the character inferences based on the observation of these behaviours. As such, the customer character orientation would be determinant in the way one evaluates the performance of a brand [3]. Taking this into account, the influence of consumer personality on consumerbrand relationship should also be indirect:

H6: The influence of Consumer Personality on Consumer-Brand Relationships will be partially mediated by the consumer perceptions of Partner Quality.

\section{Methodology}

\subsection{Brand Selection}

The study featured nine well known brands in the Portuguese market. These brands represented different product categories, brand personalities and functional versus symbolic usage. The utilitarian brands were Continente (stores/supermarkets) and Luso (mineral water). The symbolic brands were Chanel (fragrances), Ferrari (sport automobiles) and Nike (sports apparel). The both symbolic and utilitarian brands were Mercedes (automobiles), Volkswagen (automobiles) and Land Rover (sport utility vehicle-SUV). Finally, Coca-Cola (soft drink) was used as a control brand. The 2005 Superbrands Portugal [21], the 2005 Best Global Brands [22], and the information about sales performance of the Portuguese automobile industry in 2006 (supplied by the Automóvel Clube de Portugal [23]) provided guidance in the selection of the brands. Two additional aspects influenced the selection procedure. The first was that brand personality is more important in symbolic categories such as automobiles and fragrances [24]. The second was that the automobiles category is notable in terms of brand sensibility [25].

\subsection{Participants}

In order to reduce the possibility of participant fatigue, which could bias the results, two groups of four brands were presented. To ensure a close profile to the sample, each group was composed by at least: one symbolic brand, one utilitarian brand, and one utilitarian/symbolic brand. Group 1 was composed of the brands: Continente, Nike, Mercedes, Land Rover, and Coca-cola. Group 2 was composed of the brands: Luso, Volkswagen, Chanel, Ferrari, and Coca-cola. Coca-Cola was included in each group as a control element in order to assess the variations in the consumer perceptions. Coca-Cola was chosen as the control element because it is recognized as one of the most familiar brands in the world and should have no real differences in the two groups.

A total of 388 individuals participated in the study. A sample of convenience, by quotas in terms of age and gender, of 350 valid questionnaires was obtained. According to the 2001 Census [26], age and gender were not statistically significantly different from the Portuguese population (age: $(M$ sample $=40.3, M$ pop. $=39.5),(t=$ $0.97, p=0.33$ ), gender: $\left.\chi^{2}(1)=0.100, p=0.75\right)$. The respondents were between 18 and 86 years old.

The participants and the commercial brands were chosen according to the identical principles that guided the research of Jennifer Aaker and her colleagues in the North American, Japanese and Spanish markets [10,11].

\subsection{Measures}

For the sake of proven test reliability and cross cultural consistency existing and tested instruments were used to measure each one of the constructs studied. The construct of Brand Personality was measured by the Spanish Brand Personality Framework [11] (see Appendix A) according to an imposed-etic approach [27]. The construct of Consumer-Brand Relationship was assessed by the short version of Relationship Ideals Scale [12] (see Appendix B). To analyze Relationship Strength and Partner Quality, the Relationship Strength Indicators and Partner Quality scale [2] (see Appendix C), respectively, were used.

Aware of the difficult task of choosing a stable framework to access the Consumer Personality Baumgartner [28] suggests the Big Five taxonomy as a base to structure a trait specific framework to consumer behavior. The Big Five is considered the most consensual framework that explores the individual differences with an acceptable level of abstraction [14] and allows studying the human personality at the first level of analysis according to McAdams [29]. In this study, for the sake of simplicity, the construct Consumer Personality was studied through the NEO-FFI [30] which is one of the Big Five instruments. The NEO-FFI is the short version of the NEOPersonality Inventory $[13,15]$ which was translated by Margarida Lima and António Simões in 2000 (unpublished manuscript). Some psychometric studies developed by Lima [31] confirmed the reliability and predictive validity of the NEO-Personality Inventory for the Portuguese population. 


\subsection{Procedures}

The Relationship Ideals and Relationship Strength Indicators scales were translated from English to Portuguese. The Spanish Brand Personality framework was simultaneously translated from Spanish and English to Portuguese. The translations from English were assessed by two bilingual researchers and from Spanish by a bilingual researcher. In order to test content validity [32], a preliminary instrument was developed. This instrument was replicated in two questionnaires according to two different groups of three well known brands. Coca-cola was again used as the control. Forty-two questionnaires were collected by faculty, staff and post-graduate students.

The final sample was collected using non-random methods. Participants were contacted directly by undergradduate students and some other volunteers who explained the purpose of the study and distributed the questionnaire with the instructions. The participants were instructed to answer the questionnaires when alone and then to return them. Participants were not paid. Each participant answered one of the two different questionnaires (related to the two groups of brands). To avoid primacy and regency effects [10], the order in which the five brands were presented in the questionnaires and the order in which the personality and consumer-brand relationship traits appeared were rotated.

In the first section of the questionnaires the participants answered the NEO-FFI Scale. The second section of the questionnaires assessed the constructs Brand Personality, Consumer-Brand Relationship, Relationship Strength, and Partner Quality. This section was repeated for every five brands of each questionnaire. The participants were asked initially about their familiarity with the brand on a five-point Likert scale ( $1=$ I don't know the brand, $5=\mathrm{I}$ know the brand very well). The answers of the respondents who rated below three, or failed this item, were rejected unless they were (or had been) consumers/users of the brand. Respondents were then invited to fill the brand personality scale. Consumers were then asked if they used/consumed the brand, why and how long they had used it and, in the case they were not current brand users, why not. The respondents were advised to continue answering the questionnaire only in the case they were (or had been) current users of the brand. Finally, the brand users were requested to answer the Consumer-brand Relationship scale and the items related with Relationship Strength and Partner Quality.

\subsection{Sampling and Non-Response Bias}

No significant differences were found among the rates of Brand Personality, Consumer-Brand Relationship, Relationship Strength, and Partner Quality for Coca-Cola, in the two sub-samples. In order to test the conceptual model, a sample of consumer-brand relationships was extracted from the 350 valid questionnaires, according to the procedure used for sampling building by Cronin and Taylor [33]. The concern that J. Aaker's Brand Personality framework might not work in a research situation that aggregates data within a single product category [34] was a determinant in the sampling strategy. This sample included 733 consumer-brand relationships. About $80 \%$ of these relationships involved the brands Coca-Cola, Continente, Luso, and Nike, and the remained 20\% involved Volkswagen, Chanel, Mercedes, Land Rover, and Ferrari.

\section{Results}

Confirmatory Factor Analysis (CFA) and Structural Equation Modeling (SEM) were used to test the author's proposed theoretical framework (see Figure 1). Statistical software AMOS 16.0 [35] for Windows 2003 was used for estimating parameters and computing goodnessof-fit measures through Full-Information Maximum Likelihood (FIML) estimator. The hypotheses were considered acceptable when a statistical level of $p$ equal to or less than 0.05 existed.

\subsection{Reliability}

Reliabilities were calculated through Cronbach's alphas coefficients based on the items for each factor of a given scale. High internal consistency was achieved for each factor of Brand Personality (Cronbach's alphas ranged from 0.80 to 0.90 ), of Consumer-Brand Relationship (Cronbach's alphas were 0.89 and 0.91 , respectively), of Relationship Strength (Cronbach's alphas ranged from 0.87 to 0.93 ), and for the one-dimensional scale of Partner Quality (Cronbach's alpha was 0.91). With regard to Consumer Personality, high internal consistency was achieved for the measures of Neuroticism and Conscientiousness (Cronbach's alphas were, respectively, 0.82 and 0.80), and acceptable internal consistency for Extroversion and Openness (Cronbach's alpha was 0.71 in each case, above the minimum of 0.70 recommended by Nunnally, [36]). Agreeableness showed poor internal consistency with an alpha of 0.54 .

\subsection{Measurement Model}

A CFA was conducted in order to assess the correspondence between measures and data. Each item or component was restricted to load on its pre-specified factor with the five first-order factors allowed to correlate freely. The model contained five latent variables (Brand Personality, Consumer-Brand Relationship, Consumer Personality, Relationship Strength, and Partner Quality) and 22 measures. The items were averaged for each one of the components of the scales. Although Agreeableness showed poor internal consistency with a Cronbach's alpha of 
0.54 , the items were also averaged in a single factor as according to the procedure used by Bagozzi and Dholakia [37].These composite variables served as indicators in the CFA, except in the case of the one-dimensional scale of Partner Quality, where the six items served as measures. This strategy was subordinated to the minimum sample size requirements for SEM designs of a ratio of 5 cases for each estimated parameter [38].

Results, as interpreted by the goodness-of-fit measures, indicated that the model fit the data well. The chi-square of this model was significant $\left(\chi^{2}(107)=408.4, p<0.001\right)$, in opposition with the convention that an acceptable model is one that $p$ is equal or in excess of 0.05 . However, since the chi-square statistic is sensitive to sample size, additional fit measures (independent of sample size) were calculated. This model achieved 0.95, 0.96, 0.96, and 0.95 for NFI, CFI, IFI, and TLI, respectively (values of 0.90 or greater are recommended for an acceptable fit); and 0.06 for RMSEA (acceptable values range from 0.05 to 0.08 , according to Hair, Anderson, Tatham, \& Black [39]).

The analysis of the standardized loadings of each indicator on its construct, which were all statistically significant and sufficiently large, with an average loading size of 0.77 , showed evidence of convergent validity [40].

Discriminant validity was assessed in three different ways. First, we checked whether the correlations between any two constructs were significantly different from one. The test showed that the respective confidence intervals ( \pm two standard errors) do not include the value of one, suggesting evidence of discriminant validity [41]. Second, a chi-square test was performed for each pair of latent constructs on a measurement model constraining their correlation to equal one and on a baseline measurement model without this constraint. Then, the difference between these two chi-square tests was submitted again to a chi-square test for each pair of constructs, resulting in a total of 10 significant chi-square-difference tests, also providing evidence of discriminant validity [37]. Third, the shared variance among any two constructs (i.e., the square of their correlation) was then compared with both their extracted variances (i.e., average variances explained in the items by the constructs) [42]. Since the tests showed that all shared variances were less than the respective extracted variances, evidence of discriminant validity in the measures of all constructs under study was again taken for granted.

\subsection{Path Analysis Model Estimates}

Since the model showed construct validity the path diagram was estimated. The final model achieved a good fit: Chi-square $=519.0, d f=109, p<0.001, \mathrm{RMSEA}=0.07$, $\mathrm{CFI}=0.95, \mathrm{IFI}=0.95, \mathrm{NFI}=0.94$, and $\mathrm{TLI}=0.94$. Most of the direct paths proposed were statistically significant with the exception of the direct relationships between Consumer Personality and Partner Quality, Consumer Personality and Consumer-Brand Relationship, and Brand Personality and Relationship Strength (see Figure 2).

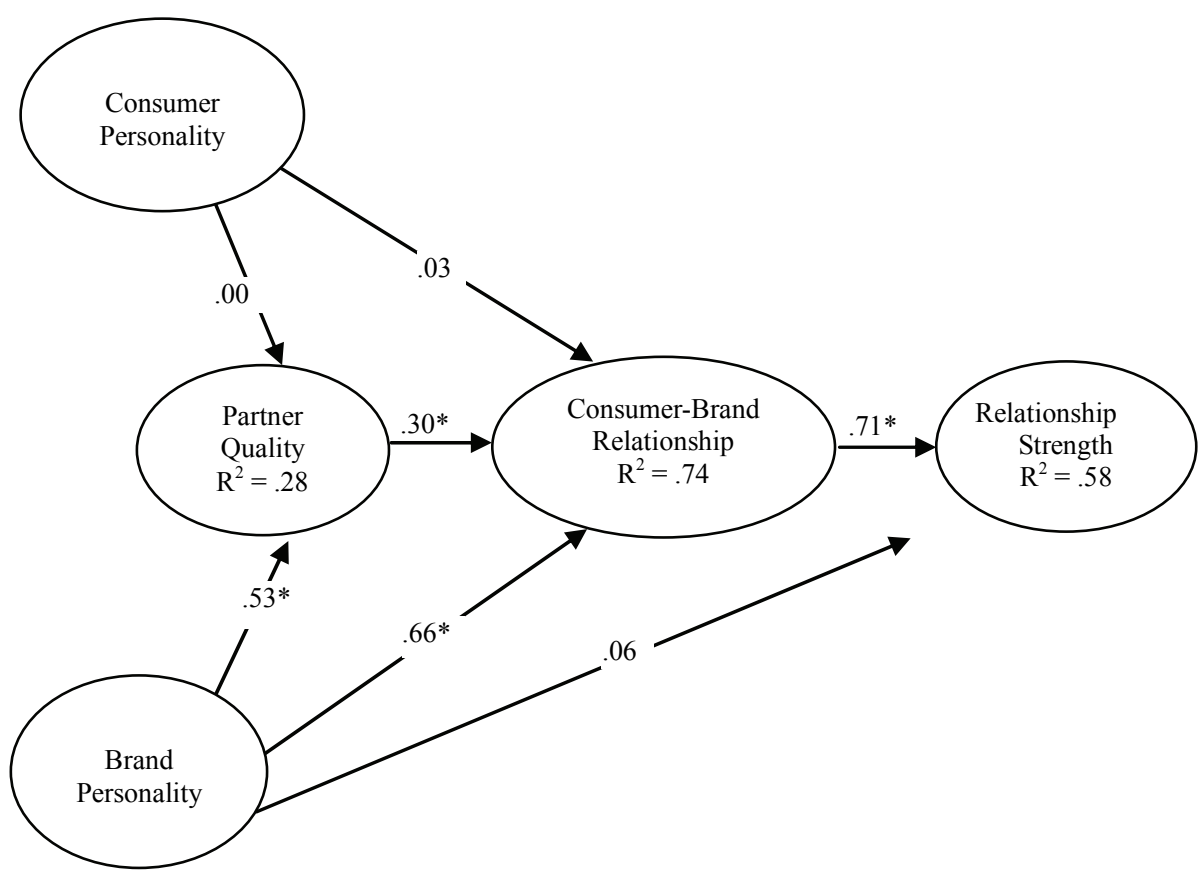

Note: The estimates were completely standardized. ${ }^{*}$ Coefficient is significant at the .001 level (2-tailed).

Figure 2. Path diagram 
As expected, the estimates confirmed that Brand Personality is a predictor of Consumer-Brand Relationships (hypothesis 1). It is interesting to note that Brand Personality had a significant positive direct effect $(0.66, p<$ 0.01 ) on Consumer-Brand Relationship. This prediction was strengthened by a significant indirect effect $(0.16, p$ $<0.01)$ through Partner Quality. Although small, this indirect effect supported the hypothesis 3 . The total effect $(0.82, p<0.01)$ showed that Brand Personality had a strong positive effect on Consumer-Brand Relationship (see Table 1). Also as expected, a positive significant effect $(0.71, p<0.01)$ of the Consumer-Brand Relationship on Relationship Strength was noted which supported hypothesis 4. Results, however, did not support the hypothesis 2 since no significant direct effect of Brand Personality on Relationship Strength was found. To the contrary, a significant indirect effect of Brand Personality on Relationship Strength $(0.58, p<0.01)$ was achieved that suggests Consumer-Brand Relationship mediates all the effects of Brand Personality on Relationship Strength.

No significant effects were found for the path of Consumer Personality on Consumer-Brand Relationship and no significant indirect effects of Consumer Personality on Consumer-Brand Relationship through Partner Quality were determined. Thus, both hypothesis 5 and hypothesis 6 were rejected.

Additionally, Partner Quality showed a moderate to small indirect effect on Relationship Strength $(0.22, p<$ 0.01) through Consumer-Brand Relationship. By contrast, no indirect effect was found for Consumer Personality on Relationship Strength through Consumer-Brand Relationship as implied in the theoretical framework.

\section{Discussion}

While recognizing the eventual influence of some external factors to this study (e.g., the product category or the context), the results demonstrated a clear contribution of brand personality on consumer-brand relationship. This provides two significant contributions that have both academic and managerial implications. First, the study em- phasizes the role of consumer-brand relationship in understanding multi-brand, symbolic consumption. Second, the study results offer a more holistic perspective in the understanding of the construct brand personality. While brand personality has been significantly studied and developed in literature with wide applications in brand management the notion of consumer-brand relationship has emerged recently and seems to lack practical implementation.

The research has further demonstrated that the concept of brand relationship is valid and helps to organize meaning in a consumer's mind. Moreover, the successful application of an interpersonal relationship inventory in a branding setting would be of particular interest to marketers and may provide a basic and a user friendly framework useful in the development of building long term relationship brand strategy.

The analysis suggests that consumer-brand relationship mediates all the effects of brand personality on relationship strength and, therefore, brand personality did not demonstrate any direct impact on relationship strength. This may indicate that although important in terms of brand image brand personality per se does not insure relationship stability and durability. The type of consumer-brand relationship may rather be an important indicator of customer loyalty. This is consistent with the literature that considers brand personality mainly a differentiating element in an environment of symbolic consumption that allows for the simplification of the process of selection, instead a direct player on the buying decision process [24]. On the other side, these results were not consistent with the conceptual model for consumer-brand relationships proposed by J. Aaker et al. [2] where a direct effect of Brand Personality on Relationship Strength was indicated. A possible explanation is that the study of J. Aaker et al. was limited to the brand personalities of Sincerity and Excitement, which are associated to two classes of brand relationships that rely on the same constructs of the Intimacy-Loyalty and Passion relationships.

Table 1. Standardized effects of the structural model

\begin{tabular}{|c|c|c|c|c|c|c|c|c|c|}
\hline & \multicolumn{3}{|c|}{ Partner Quality } & \multicolumn{3}{|c|}{ Consumer-Brand R. } & \multicolumn{3}{|c|}{ Relationship Strength } \\
\hline & Direct & Indirect & Total & Direct & Indirect & Total & Direct & Indirect & Total \\
\hline BP & $0.53^{*}$ & & $0.53^{*}$ & $0.66^{*}$ & $0.16^{*}$ & $0.82 *$ & 0.06 & $0.58^{*}$ & $0.64^{*}$ \\
\hline C-BR & & & & & & & $0.71 *$ & & $0.71 *$ \\
\hline $\mathrm{CP}$ & 0.00 & & 0.00 & 0.03 & & 0.03 & & 0.02 & 0.02 \\
\hline \multicolumn{10}{|l|}{$\mathrm{RS}$} \\
\hline PQ & & & & $0.30 *$ & & $0.30^{*}$ & & $0.22 *$ & $0.22 *$ \\
\hline
\end{tabular}

(Note: Values in cells are completely standardized estimates. The rounding is the cause of some discrepancies between total effects and the respective direct effect plus the indirect effect. $\mathrm{BP}=$ Brand personality, C-BR $=$ Consumer-Brand Relationship, $\mathrm{CP}=\mathrm{Consumer}$ Personality, $\mathrm{RS}=\mathrm{Relationship}$ Strength, $\mathrm{PQ}=$ Partner Quality. ${ }^{*}$ Coefficient is significant at the 0.01 level (2-tailed).) 
Although consumer-brand relationship was measured by a scale of attributes, the study of this phenomenon is not limited to attitudinal aspects. The behavioral component of brand relationships is captured by relationship strength through Commitment (see Appendix C). This behavioral component reflects operational investments in committed and lasting relationships and can be considered behavioral indicators of loyalty [43].

\section{Conclusions}

It has been suggested that loyalty is a reflection of buyer brand commitment and an expression of relationship depth. As described by the author's conceptual model (see Figure 1), the consumer's brand relationship strength is a determinate of consumer personality, brand personality, partner quality and the resulting consumer brand relationship. As such, the consumer's relationship with a brand is certainly a gestalt with the whole greater than the sum of the parts. Actual brand loyalty results when a consumer's intellectual and emotional relationship with a brand is sufficient to commit that customer to pay higher prices seek out brand/products for repurchase and are a source of referrals. Given this complexity, it is not surprising that the author's did not find a meaningful correlation between brand personality and relationship strength. It was, however, less problematical to demonstrate the connection between brand personality with consumer brand relationships. The consumer's relationship with a brand is dynamic and formed by the consumer's perception of both the actual physical as well as the psychological elements of the product. It is this combination, and its relationship to price, which creates a consumer's impression of value. The evaluation of a product's physical aspects tends to be intellectual based on information about actual product features. The psychological aspect of the product as discussed is an emotional relationship formed by consumer beliefs and needs not to be rational.

One aspect of attempts to bond brands and personality relates to the manipulation of the non physical aspects of the brand personality characteristics. This often is to either maintain brand loyal customers or conversely steal shifting or disloyal customers from competing brands. There is a danger in relying on brand strategies that focus on the psychological repositioning, as opposed to actual product modification. The danger is that today's sophisticated consumer, utilizing internet driven information, is no longer easily deceived by campaigns designed to promote an "illusion" of change to strengthen brand personality with little actual price or product modifications. This is a clear warning that it is unlikely that Ford's hollow slogan "Quality is job one", which may have stirred emotions and enhanced relationships in the 1980s, would be accepted by today's intense consumer scrutiny. This would reinforce that obtaining an in depth understanding of both the consumer brand relationship as well as the underlying relationship strength is essential. This is true as this understanding yields information about the degree of the bond strength between product/company and consumer. The delicate nature of a brand bond is illustrated by the difficulty of the author's to demonstrate a relationship between brand personality and relationship strength.

Fournier and Lee [44] point to the need to fashion a flexible brand relationship that allows individuals to adopt new roles as lives, ages and values change. The author's model would suggest that, while needing to be adaptable to life and company changes, for the consumer brand relationship to be maintained, the company must be careful to assure that both the consumer's personality and the brand's personality remain in equilibrium over time and environmentally related incidences.

One environmental threat to the equilibrium, which has not been adequately addressed by firms, relates to the new internet information age consisting of twittering, blogs and web ratings. These instant sources of communication have made it possible, due to widespread and low cost information, for rapid disruptions in a brand's image to occur for legitimate or irrational reasons. It would seem that such disruptions could put pressures on the consumer relationship by altering brand perception. Fears resulting from sufficient actual incidences over the past five years have resulted in the increased importance of corporate business continuity programs whose major responsibility is the mitigation of threats to the brand which could cause a shift in the relationship equilibrium. Reinforcing the importance of the consumer as a partner in the relationship, firms must have a comprehensive understanding of how the personalities of their consumer relate to partner quality and the consumer brand relationship. This is essential if they are to effectively react to any incident of imbalance which could result in a shift in consumer brand preferences and thus a loss in consumers. Favaro, Romberger, and Meer [45], for example, state that even downturns in business cycles present opportunities for firms to capture shifting loyal and non loyal consumers from competitors. They recommend that companies seize such opportunities to redirect shifters toward their product choices. While taking what some might consider an "older perspective" by stating that loyals are too costly to redirect it is possible that a broader understanding of the constructs underlying the consumer brand relationship may make attacks on loyals highly feasible.

\section{Limitations and Suggestions for Further Research}

Regarding the role of consumer personality on the estab- 
lishment of consumer-brand relationships, the studies provided no relevant outcomes. It is interesting to note that the influence of consumer personality on consumers' brand evaluation seems to be clear according to the literature. This result could be influenced by the fact that, although a consensual framework in the psychology field, the Big Five model of human personality has not been greatly explored in terms of consumer behavior [28]. Thus, this initiative may offer an exploratory basis for further developments of the applicability of the Big Five to the consumer behavior context.

Another possible explanation for the lack of interesting effects relating to the consumer personality construct may be the fact that confidentiality in the responses was not always ensured, as the questionnaires were returned directly to the volunteers that collected the data. Since the questions under the rubric of consumer personality dealt with personal and, perhaps, intimate information, this problem should be addressed in future research.

When interpreting these findings one should have in mind that product category interactions might bias results. Thus, although this research relied on a rich database, future researchers may expand the number of different categories. It may also be advisable that more brand personalities (both utilitarian and symbolic) be introduced to further extend the findings to a larger domain. In particular, two different brands in a single product category might be a good way of controlling the likable product category influence on brand image [46]. In respect to the brand personality framework, significant differences were found only for symbolic or both symbolic and utilitarian brands rather than for utilitarian brands (Continente and Luso). This may be, however, a confirmation of the relative importance of brand personality construct in less symbolic categories.

\section{Acknowledgements}

To Fundação para a Ciência e a Tecnologia (FCT) that supported this study.

\section{REFERENCES}

[1] D. A. Aaker, "Building Strong Brands," Free Press, New York, 1996.

[2] J. Aaker, S. Fournier and S. A. Brasel, "When Good Brands Do Bad," Journal of Consumer Research, Vol. 31, No. 1, 2004, pp. 1-16.

[3] P. Aggarwal, "The Effects of Brand Relationship Norms on Consumer Attitudes and Behavior," Journal of Consumer Research, Vol. 31, No. 1, 2004, pp. 87-101.

[4] M. Blackston, "Beyond Brand Personality: Building Brand Relationships," In: D. A. Aaker \& A. L. Biel, Eds., Brand Equity and Advertising: Advertising's Role in Building Strong Brands, Lawrence Erlbaum, Hilsdale, New Jersey, 1993, pp. 113-124.
[5] S. Fournier, "Toward the Development of Relationship Theory at the Level of the Product and Brand," In: F. R. Kardes and M. Sujan, Eds., Advances in Consumer Research, Association for Consumer Research, Provo, Vol. 22, 1995, pp. 661-662.

[6] S. Fournier, "Consumers and their Brands: Developing Relationship Theory in Consumer Research," Journal of Consumer Research, Vol. 24, No. 4, 1998, pp. 343-373.

[7] S. Fournier and J. L. Yao, "Reviving Brand Loyalty: A Reconceptualization within the Framework of ConsumerBrand Relationships (Working Paper)," Harvard Business School, Boston, 1996.

[8] J. Jacoby and R. Chestnut, "Brand Loyalty," Ronald Press, New York, 1978.

[9] K. L. Keller, "Brand Synthesis: The Multidimensionality of Brand Knowledge," Journal of Consumer Research, Vol. 29, 2003, pp. 595-600.

[10] J. L. Aaker, "Dimensions of Brand Personality," Journal of Marketing Research, Vol. 34, No. 3, 1997, pp. 347-356.

[11] J. L. Aaker, V. Benet-Martinez and J. Garolera, "Consumption Symbols as Carriers of Culture: A Study of Japanese and Spanish Brand Personality Constructs. Journal of Personality and Social Psychology, Vol. 81, No. 3, 2001, pp. 492-508.

[12] G. J. O. Fletcher, J. A. Simpson, G. Thomas and L. Giles, "Ideals in Intimate Relationships," Journal of Personality and Social Psychology, Vol. 76, No. 1, 1999, pp. 72-89.

[13] P. T. Jr. Costa and R. R. McCrae, "The NEO Personality Manual," Psychological Assessment Resources, Odessa, 1985.

[14] O. P. John and S. Srivastava, "The Big Five Trait Taxonomy: History, Measurement, and Theoretical Perspectives," In: L. A. Pervin and O. P. John, Eds., Handbook of Personality: Theory and Research, 2nd Edition, Guildford Press, New York, 1999, pp. 102-138.

[15] R. R. McCrae and P. C. Jr. Costa, "The Structure of Interpersonal Traits: Wiggins's Circumplex and the FiveFactor Model," Journal of Personality and Social Psychology, Vol. 56, No. 4, 1989, pp. 586-595.

[16] I. Altman and D. A. Taylor, "Social Penetration: The Development of Interpersonal Relationships," Holt, Rinehart and Winston, New York, 1973.

[17] D. E. Allen and J. Olson, "Conceptualizing and Creating Brand Personality: A Narrative Theory Approach," In: J. Aaker \& S. Fournier, Eds., A Brand as a Character, a Partner and a Person: Three Perspectives on the Question of Brand Personality, pp. 392-393; In: F. R. Kardes \& M. Sujan, Eds., Advances in Consumer Research, Association for Consumer Research, Provo, UT, Vol. 22, 1995, pp. 391-395.

[18] K. Storbacka, T. Strandvik and C. Grönroos, "Managing Customer Relationships for Profit: The Dynamics of Relationship Quality," International Journal of Service Industry Management, Vol. 5, No. 5, 1994, pp. 21-38.

[19] M. S. Clark, R. Ouellette, M. C. Powell and S. Milberg, "Recipient's Mood, Relationship Type and Helping," 
Journal of Personality and Social Psychology, Vol. 53, No. 1, 1987, pp. 94-103.

[20] A. E. Auhagen and R. A. Hinde, "Individual Characteristics and Personal Relationships," Personal Relationships, Vol. 4, No. 11, 1997, pp. 63-84.

[21] Superbrands, "Superbrands Portugal 2005," Retrieved February 2007. http://www.superbrands. com

[22] Interbrand, "The 100 Best Global Brands by Value 2005," Retrieved April 2006. http://www.interbrand. com

[23] Automóvel Club de Portugal, "Análise de Mercado em 2006," Retrieved October 2006. http://autos.acp.pt/pdf/ 2006.pdf

[24] J. Lannon, "Asking the Right Questions: What do People Do with Advertising?" In: D. A. Aaker \& A. Biel, Eds., Equity and Advertising: Advertising's Role in Building Strong Brands, Lawrence Erlbaum, Hilsdale, New Jersey, 1993, pp. 143-162.

[25] J. Kapferer and G. Laurent, "La sensibilité aux marques," In: J. Kapferer \& J. Thoenig, Eds., La Marque: Moteur de la Competitivité des Entreprises et de la Croissance de l'Économie, McGraw- Hill, Paris, 1989, pp. 93-124.

[26] Instituto Nacional de Estatística, "Census 2001-Resultados Definitivos," INE, Portugal, 2002.

[27] J. W. Berry, "On Cross-Cultural Comparability," International Journal of Psychology, Vol. 4, No. 2, 1969, pp. 119-128.

[28] H. Baumgartner, "Toward a Personology of the Consumer," Journal of Consumer Research, Vol. 29, No. 2, September 2002, pp. 286-292.

[29] D. P. McAdams, "What do We Know when We Know a Person?" Journal of Personality, Vol. 63, No. 3, 1995, pp. 365-396.

[30] P. T. Jr. Costa and R. R. McCrae, "Revised NEO Personality Inventory (NEO-PI-R) and NEO Five-Factor Inventory (NEO-FFI) Professional Manual," Psychological Assessment Resources, Odessa, 1992.

[31] M. P. Lima, "NEO-PI-R: Contextos teóricos e Psicométri-cos 'OCEAN' ou 'Iceberg'?' Unpublished Doctoral Dissertation, Faculdade de Psicologia e Ciências da Educação, Universidade de Coimbra, Portugal, 1997.

[32] A. Lancastre and L. F. Lages, "The Relationship between Buyer and a B2B e-Marketplace: Cooperation Determinants in an Electronic Market Context," Industrial Marketing Management, Vol. 35, 2006, pp. 774-789.
[33] J. J. Jr. Cronin and S. A. Taylor, "Measuring Service Quality: A Reexamination and Extension," Journal of Marketing, Vol. 56, No. 3, 1992, pp. 55-68.

[34] J. R. Austin, J. A. Siguaw and A. S. Mattila, “A Re-Examination of the Generalizability of the Aaker Brand Personality Measurement Framework," Journal of Strategic Marketing, Vol. 11, No. 2, 2003, pp. 77-92.

[35] J. L. Arbuckle, “Amos 16.0 User's Guide,” Amos Development, Spring House, 2007.

[36] J. C. Nunnally, "Psychometric Theory," Mc-Graw-Hill, New York, 1978.

[37] R. P. Bagozzi and U. M. Dholakia, "Antecedents and Purchase Consequences of Customer Participation in Small Group Brand Communities," International Journal of Research in Marketing, Vol. 23, No. 1, 2006, pp. 4561.

[38] P. M. Bentler, "EQS Manual," BMDP, Los Angeles, CA, 1989.

[39] J. F. Jr. Hair, R. E. Anderson, R. L. Tatham and W. C. Black, "Multivariate Data Analysis: With Readings," 5th Edition, Prentice Hall, London, 1998.

[40] R. P. Bagozzi and G. R. Foxall, "Construct Validation of a Measure of Adaptative-Innovative Cognitive Styles in Consumption," International Journal of Research in Marketing, Vol. 13, No. 3, 1996, pp. 201-213.

[41] J. Anderson and D. Gerbing, "Structural Equation Modeling in Practice: A Review and Recommended Two-Step Approach," Psychological Bulletin, Vol. 103, No. 3, 1988, pp. 411-423.

[42] C. Fornell and D. F. Larcker, "Evaluating Structural Equation Models with Unobservable Variables and Measurement Error," Journal of Marketing Research, Vol. 18, No. 1, 1981, pp. 39-50.

[43] G. T. Gundlach, R. S. Achrol and J. T. Mentzer, "The Structure of Commitment in Exchange," Journal of Marketing, Vol. 59, No. 1, 1995, pp. 78-92.

[44] S. Fournier and L. Lee, "Getting Brand Communities Right," Harvard Business Review, 2009, pp. 105-111.

[45] K. Favaro, T. Romberger and D. Meer, "Five Rules for Retailing in a Recession," Harvard Business Review, 2009.

[46] A. Drolet and J. Aaker, "Off-Target? Changing Cognitive-Based Attitudes," Journal of Consumer Psychology, Vol. 12, No. 1, 2002, pp. 59-68. 


\section{APPENDIX A. Brand Personality Dimensions}

\begin{tabular}{|c|c|c|c|}
\hline Dimension & $\begin{array}{l}\text { Original Spanish (Castilian) } \\
\text { term } \\
\text { (J. Aaker et al., 2001) }\end{array}$ & $\begin{array}{l}\text { Original English } \\
\text { translation } \\
\text { (J. Aaker et al., 2001) }\end{array}$ & Portuguese translation \\
\hline \multirow[t]{9}{*}{ Excitement } & alegre & happy & alegre \\
\hline & extrovertida & outgoing & extrovertida \\
\hline & divertida & fun & divertida \\
\hline & atrevida & daring & ousada \\
\hline & jovem & young & jovem \\
\hline & viva & spirited & viva \\
\hline & única & unique & única \\
\hline & creativa & imaginative & criativa \\
\hline & independiente & independent & independente \\
\hline \multirow[t]{6}{*}{ Sincerity } & considerada & considerate & ponderada \\
\hline & atenta & thoughtful & atenta \\
\hline & correcta & well mannered & correcta \\
\hline & real & real & real \\
\hline & sincera & sincere & sincera \\
\hline & realista & down-to-earth & realista \\
\hline \multirow[t]{6}{*}{ Sophistication } & elegante & good looking & elegante \\
\hline & glamorosa & glamorous & com glamour \\
\hline & moderna & stylish & moderna \\
\hline & segura de si misma & confident & segura de si mesma \\
\hline & persistente & persistent & persistente \\
\hline & dirigente & leader & líder \\
\hline \multirow[t]{6}{*}{ Peacefulness } & cariñosa & affectionate & carinhosa \\
\hline & dulce & sweet & doce \\
\hline & amable & gentle & amável \\
\hline & ingenua & naive & ingénua \\
\hline & apacible & mild mannered & afável \\
\hline & pacífica & peaceful & pacifica \\
\hline \multirow[t]{6}{*}{ Passion } & fervorosa & fervent & fervorosa \\
\hline & apasionada & passionate & apaixonada \\
\hline & intensa & intense & intensa \\
\hline & espiritual & spiritual & espiritual \\
\hline & mística & mystical & mística \\
\hline & bohemia & bohemian & boémia \\
\hline
\end{tabular}

\section{APPENDIX B. Consumer-Brand Relationship Dimensions}

\begin{tabular}{lll}
\hline Relationship type & \multicolumn{1}{c}{$\begin{array}{c}\text { Original English term } \\
\text { (Fletcher et al., 1999) }\end{array}$} \\
\hline Passion & exciting & Portuguese translation \\
& challenging & entusiasmante \\
& humorous & estimulante \\
& fun & com humor \\
& independence & divertida \\
& passionate & independente \\
& honest & apaixonada \\
\hline Intimacy-loyalty & commitment & honesta \\
& caring & comprometida \\
& trusting & que cuida dos outros \\
& support & de confiança \\
& respect & que dá apoio \\
& & de respeito \\
\hline
\end{tabular}




\section{APPENDIX C . Relationship Strength and Partner Quality Dimensions}

\begin{tabular}{|c|c|c|}
\hline Measure & Items & Items \\
\hline & $\begin{array}{l}\text { Original English version for the study of } \\
\text { Captura brand (J. Aaker et al., 2004, 8) }\end{array}$ & $\begin{array}{l}\text { Portuguese version for the Questionnaires of } \\
\text { Relationship Strength and Partner Quality }\end{array}$ \\
\hline \multicolumn{3}{|l|}{$\begin{array}{l}\text { Relationship } \\
\text { strength indicators: }\end{array}$} \\
\hline \multirow[t]{5}{*}{ Commitment } & $\begin{array}{l}\text { "I am very loyal to Captura." } \\
\text { "I am willing to make small sacrifices in } \\
\text { order to keep using Captura." }\end{array}$ & $\begin{array}{l}\text { "Eu sou muito leal à Coca-Cola*." } \\
\text { "Estou na disposição de fazer pequenos } \\
\text { sacrifícios de forma a poder continuar a } \\
\text { consumir Coca-Cola." }\end{array}$ \\
\hline & $\begin{array}{l}\text { "I would be willing to postpone my purchase } \\
\text { if the Captura site was temporarily } \\
\text { unavailable." }\end{array}$ & $\begin{array}{l}\text { "Estaria na disposição de adiar a minha compra } \\
\text { se a Coca-Cola estivesse temporariamente } \\
\text { indisponível nos pontos de venda." }\end{array}$ \\
\hline & $\begin{array}{l}\text { "I would stick with Captura even if it let me } \\
\text { down once or twice." }\end{array}$ & $\begin{array}{l}\text { "Continuaria consumidor da Coca-Cola mesmo } \\
\text { se ela me desapontasse uma ou duas vezes." }\end{array}$ \\
\hline & $\begin{array}{l}\text { "I am so happy with Captura that I no longer } \\
\text { feel the need to watch out for other } \\
\text { photography alternatives." }\end{array}$ & $\begin{array}{l}\text { "Estou tão contente com a Coca-Cola que não } \\
\text { sinto necessidade de estar atento a outras } \\
\text { alternativas." }\end{array}$ \\
\hline & $\begin{array}{l}\text { "I am likely to be using Captura one year } \\
\text { from now." }\end{array}$ & $\begin{array}{l}\text { "Provavelmente, vou continuar a consumir } \\
\text { Coca-Cola num futuro próximo." }\end{array}$ \\
\hline \multirow[t]{5}{*}{ Intimacy } & $\begin{array}{l}\text { "I would feel confortable sharing detailed } \\
\text { personal info about my self with Captura." }\end{array}$ & $\begin{array}{l}\text { "Sentia-me confortável se partilhasse } \\
\text { informação pessoal detalhada sobre mim com } \\
\text { a Coca-Cola." }\end{array}$ \\
\hline & $\begin{array}{l}\text { "Captura really understands my needs in the } \\
\text { photographic services category." }\end{array}$ & $\begin{array}{l}\text { "A Coca-Cola entende realmente as minhas } \\
\text { necessidades na sua categoria de produto." }\end{array}$ \\
\hline & $\begin{array}{l}\text { "I'd feel comfortable describing Captura to } \\
\text { someone who was not familiar with it." }\end{array}$ & $\begin{array}{l}\text { "Sentia-me confortável em falar da Coca-Cola } \\
\text { a alguém que não a conhecesse." }\end{array}$ \\
\hline & $\begin{array}{l}\text { "I am familiar with the range of products } \\
\text { and services Captura offers." }\end{array}$ & $\begin{array}{l}\text { "Conheço bem os produtos e serviços que a } \\
\text { Coca-Cola oferece." }\end{array}$ \\
\hline & $\begin{array}{l}\text { "I have become very knowledgeable about } \\
\text { Captura." }\end{array}$ & "Estou muito informado acerca da Coca-Cola." \\
\hline \multirow[t]{3}{*}{ Satisfaction } & "I am completely satisfied with Captura." & $\begin{array}{l}\text { "Estou completamente satisfeito com a Coca- } \\
\text { Cola." }\end{array}$ \\
\hline & "I am completely pleased with Captura." & $\begin{array}{l}\text { "Estou completamente deleitado com a Coca- } \\
\text { Cola." }\end{array}$ \\
\hline & $\begin{array}{l}\text { "Captura is turning out better than I } \\
\text { expected." }\end{array}$ & $\begin{array}{l}\text { "A Coca-Cola está revelar-se melhor do que eu } \\
\text { esperava." }\end{array}$ \\
\hline \multirow[t]{4}{*}{ Self-Connection } & $\begin{array}{l}\text { "The Captura brand connects with the part } \\
\text { of me that really makes me tick." } \\
\text { "The Captura brand fits well with my } \\
\text { current stage of life". }\end{array}$ & $\begin{array}{l}\text { "A marca Coca-Cola associa-se a uma parte de } \\
\text { mim que realmente me entusiasma." } \\
\text { "A marca Coca-Cola corresponde bem à minha } \\
\text { actual fase de vida." }\end{array}$ \\
\hline & $\begin{array}{l}\text { "The Captura brand says a lot about the } \\
\text { kind of person I would like to be." }\end{array}$ & $\begin{array}{l}\text { "A marca Coca-Cola tem muito a ver com a } \\
\text { pessoa que eu gostaria de ser." }\end{array}$ \\
\hline & $\begin{array}{l}\text { "Using Captura lets me be a part of a shared } \\
\text { community of like-minded consumers." }\end{array}$ & $\begin{array}{l}\text { "Consumir Coca-Cola faz-me pertencer a uma } \\
\text { comunidade partilhada por consumidores com } \\
\text { interesses parecidos." }\end{array}$ \\
\hline & $\begin{array}{l}\text { "The Captura brand makes a statement } \\
\text { about what is important to me in life." }\end{array}$ & $\begin{array}{l}\text { "A marca Coca-Cola exprime aquilo que é } \\
\text { importante para mim na vida." }\end{array}$ \\
\hline
\end{tabular}




\begin{tabular}{|c|c|c|}
\hline \multirow[t]{6}{*}{ Partner Quality } & $\begin{array}{l}\text { "I can always count on Captura to do what's } \\
\text { best." }\end{array}$ & $\begin{array}{l}\text { "Posso sempre contar com a Coca-Cola para } \\
\text { fazer o que é melhor." }\end{array}$ \\
\hline & $\begin{array}{l}\text { "If Captura makes a mistake, it will try its } \\
\text { best to make up for it." }\end{array}$ & $\begin{array}{l}\text { "Se a Coca-Cola cometer um erro, ela fará o } \\
\text { seu melhor para resolver o sucedido." }\end{array}$ \\
\hline & $\begin{array}{l}\text { "I know I can hold Captura accountable for } \\
\text { its actions." }\end{array}$ & $\begin{array}{l}\text { "Eu sei que posso esperar que a Coca-Cola se } \\
\text { responsabilize pelas suas acções." }\end{array}$ \\
\hline & "Captura is reliable." & "A Coca-Cola é fiável." \\
\hline & $\begin{array}{l}\text { "Given my image of Captura, letting me } \\
\text { down would surprise me." }\end{array}$ & $\begin{array}{l}\text { "Dada a imagem que eu tenho da Coca-Cola, } \\
\text { surpreendia-me se ela me desapontasse." }\end{array}$ \\
\hline & $\begin{array}{l}\text { "A brand failure would be inconsistent with } \\
\text { my expectations." }\end{array}$ & $\begin{array}{l}\text { "Uma falha da marca seria inconsistente com } \\
\text { as minhas expectativas." }\end{array}$ \\
\hline
\end{tabular}

